\title{
Electrical Characterization and Interface State Density in Au/n-InN/InP Schottky Diode
}

\author{
A.H. Khediri ${ }^{1,2, *}$, A. Talbi ${ }^{1, \dagger}$, M.A. Benamara ${ }^{1}$ Z. Benamara ${ }^{1}$ \\ ${ }_{1}$ Laboratoire de Microélectronique Appliquée, Université Djillali Liabès de Sidi Bel Abbès, 22000, Algeria \\ 2 Plateforme Technologique de Micro-fabrication, Centre de Développement des Technologies Avancées, Cité 20 août \\ 1956, Baba Hassen, 16303 Algiers, Algeria
}

(Received 21 March 2021; revised manuscript received 04 August 2021; published online 20 August 2021)

\begin{abstract}
In this paper, we present an electrical study of InN thin films elaborated by nitridation of $\operatorname{InP}(100)$ substrates. The samples have been obtained using a glow discharge source (GDS) in ultra-high vacuum. The gold $(\mathrm{Au})$ Schottky contact was deposited on the top of the surface. The electrical characteristics of $\mathrm{Au} / \mathrm{InN} / n$-InP structure have been investigated using current-voltage and capacitance-voltage methods. We show from the current-voltage characterization at room temperature that the main conduction mechanism is thermionic emission current. A value of 1.57 for the ideality factor of the diode is extracted using analytical methods. Furthermore, the barrier height of the device is evaluated to $0.64 \mathrm{eV}$. This value is substantially larger than previously reported in the literature. The low saturation current and series resistance $\left(R_{s}\right)$ of $12.3 \mu \mathrm{A}$ and $38 \Omega$, respectively, indicate the presence of the InN layer. From the capacitance-voltage technique under reverse bias, the built-in potential and the ionized donor concentration are $0.83 \mathrm{~V}$ and $1.16 \times 10^{17} \mathrm{~cm}^{-3}$, respectively. A frequency dependent capacitance is measured and attributed to the presence of interface states. Based on the high-low frequency method, we determined the average density of interface states $(N s s)$ with a value of $5.6 \times 10^{11} \mathrm{eV}^{-1} \mathrm{~cm}^{-2}$. These findings reveal good passivation of the InP surface with the use of a thin InN film.
\end{abstract}

Keywords: Barrier height, Current-voltage measurements, Indium phosphide, Indium nitride, Interface state density, Schottky diodes.

DOI: 10.21272/jnep.13(4).04002

PACS numbers: 85.30.Kk, 85.30.Hi

\section{INTRODUCTION}

Indium nitride $(\mathrm{InN})$ semiconductor is a very interesting and highly promising material for future highperformance devices. Besides its application based on group III nitride alloys which allows tuning of the band gap and emission wavelength ranging from the near infrared (IR) to ultraviolet (UV) region, InN is expected to be a suitable material for electronic devices, such as high-efficiency solar cells, high-speed and highfrequency electronic devices, high electron mobility transistors etc., because of its superior electron transport properties [1]. The most remarkable properties of InN are its direct narrow band gap $(0.7-0.9 \mathrm{eV})$ and low electron effective mass in comparison with other nitrides, which results in high mobility and high saturation velocity.

Good quality InN layers are difficult to grow because of the low dissociation temperature of $\mathrm{InN}$ and the lack of an appropriate substrate [2]. Sapphire substrate has been widely used for the epitaxial growth of Ill-V nitrides. However, InP is a suitable III-V semiconductor substrate, having smaller lattice mismatch and a closer thermal expansion coefficient with nitride than that of sapphire.

Various growth techniques have been explored, such as reactive radio frequency $(\mathrm{RF})$ sputtering, reactive evaporation, dual ion beam sputtering, ion plating, and chemical vapor deposition (CVD), in an attempt to maintain InN film growth at a sufficiently low temperature. InP substrate surface nitridation at a lower temperature is found to be one of solutions to obtain
InN buffer layers before the InN films growth. Different methods have been investigated for the nitridation of InP (100) surfaces [3], in our study we have used the plasma nitridation method. To understand properties of the InN/InP interface obtained by nitridation, electrical characterization of Schottky diodes based on the InP and InN components has been the subject of several recent studies [3, 4]. Talbi et al. realized Schottky diodes based on InN/InP with mercury $(\mathrm{Hg})$ contact. This paper deals with the study of interface/surface defect states in the fabricated $\mathrm{Au} / \mathrm{InN} / \mathrm{InP}$ Schottky diode. Electrical characterization (current-voltage, capacitance-voltage) and analytical methods are used in order to study the $\mathrm{Au} / \mathrm{InN} / \mathrm{InP}$ diode parameters. The distribution of the interface state density $\left(N_{S S}\right)$ within the band gap obtained from both $I-V$ and $C-V$ characteristics is investigated.

\section{EXPERIMENTAL PROCEDURE}

The substrate $n$-type $\operatorname{InP}(100)$ with a carrier concentration of $1 \times 10^{16} \mathrm{~cm}^{-3}$ is used in the present work. Prior to the surface nitridation, the InP wafer is chemically cleaned by $\mathrm{H}_{2} \mathrm{SO}_{4}, 3 \%$ bromine methanol and deionized water. The InN thin film is prepared by nitridation of the InP substrates using a glow discharge source (GDS) in ultra-high vacuum $\left(10^{-6}\right.$ to $\left.10^{-7} \mathrm{~Pa}\right)$. After introduction into the chamber reactor, in situ ionbombardment cleaning with low-energy $\mathrm{Ar}^{+}$ions is performed (300 eV, sample current density $\left.2 \mathrm{~A} \cdot \mathrm{cm}^{-2}\right)$. This step removes all amount of carbon and oxygen contaminant and creates metallic indium droplets at the sub-

\footnotetext{
*abdelkrim.khediri@gmail.com

$\dagger$ talbi a02@yahoo.fr
} 
strate surface [5]. Through the consumption of indium droplets by nitrogen atoms in the plasma discharge cell, a thin film of about $25 \AA$ was created on the top of the substrate [6]. Continuous plasma is used as a nitrogen source and the substrate is heated to $250{ }^{\circ} \mathrm{C}$. We have used the nitrogen flow at $45^{\circ}$ versus the normal of the surface during $40 \mathrm{~min}$.

To realize the metal contact, a gold $(\mathrm{Au})$ gate with $2 \mathrm{~mm}$ diameter is used. The structure is described in Fig. 1. The current-voltage $(I-V)$ and capacitancevoltage $(C-V)$ measurements are carried out by Agilent 4284A, Semiconductor Parameter Analyzer and Agilent 4156C measuring instrument at room temperature.

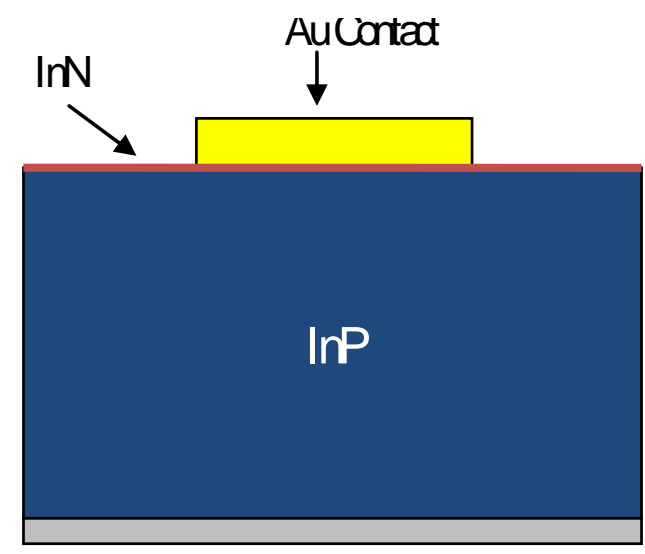

BadksideOrmic Contad

Fig. 1 - Schematic of fabricated Au/InN/n-InP Schottky diode

\section{RESULTS AND DISCUSSION}

\subsection{Current-Voltage Characteristics}

The current-voltage characteristic measured at $300 \mathrm{~K}$ is reported in Fig. 2. The forward-bias current due to thermionic emission (T.E.) across Schottky contacts with series resistance $\left(R_{s}\right)$ is given as [7]:

$$
I=I_{0}\left(\exp \left(\frac{q V-I R_{s}}{n k T}\right)-1\right)
$$

where $I_{0}$ is the saturation current, $n$ is the ideality factor, $k$ is the Boltzmann constant, and $T$ is the measurement temperature in Kelvin. The saturation current $I_{0}$ is expressed by:

$$
I_{0}=A A^{*} T^{2} \exp \left(\frac{-q \Phi_{b n}}{k T}\right),
$$

where $A$ is the contact area, $A^{*}$ is the effective Richardson constant, $q$ is the electron charge, $\Phi_{b n}$ is the barrier height. By using an effective mass of $0.073 m_{e}$ for the InP substrate [8], the value of $A^{*}$ is calculated to be $9.4 \mathrm{~A} \cdot \mathrm{cm}^{-2} \cdot \mathrm{K}^{-2}$.

Using a linear curve fit to the forward characteristics of $\log (I)-V$ versus $V$ in the first region, as shown in Fig. 2, the ideality factor $n$ and the barrier height $\Phi_{b n}$ can be calculated. The ideality factor is a measure of the conformity of the diode to pure thermionic emission and is determined from the slope of the forward bias $I$ - $V$ characteristics through the relation:

$$
n=\frac{q}{k T} \frac{d\left(V-I R_{S}\right)}{d(\ln I)}
$$

The saturation current $I_{0}$ is obtained using the intercept on the current axis of the characteristic given in Fig. 2 for the first region. Then, the saturation current is estimated to be $12.3 \times 10^{-6} \mathrm{~A}$.

The ideality factor of $\mathrm{Au}-\mathrm{InN} / \mathrm{InP}$ diode is found to be equal to 1.57 which indicates dominant thermionic conduction current. The barrier height $\Phi_{b n}$ is given by:

$$
\Phi_{b n}=\frac{q}{k T} \ln \left(\frac{A A^{*} T^{2}}{I_{0}}\right) .
$$

From Eq. (4), the calculated value of the barrier height is $0.64 \mathrm{eV}$ which is higher than the barrier value (0.40-0.55 eV) of the conventional Au/InP diode [9, 10].

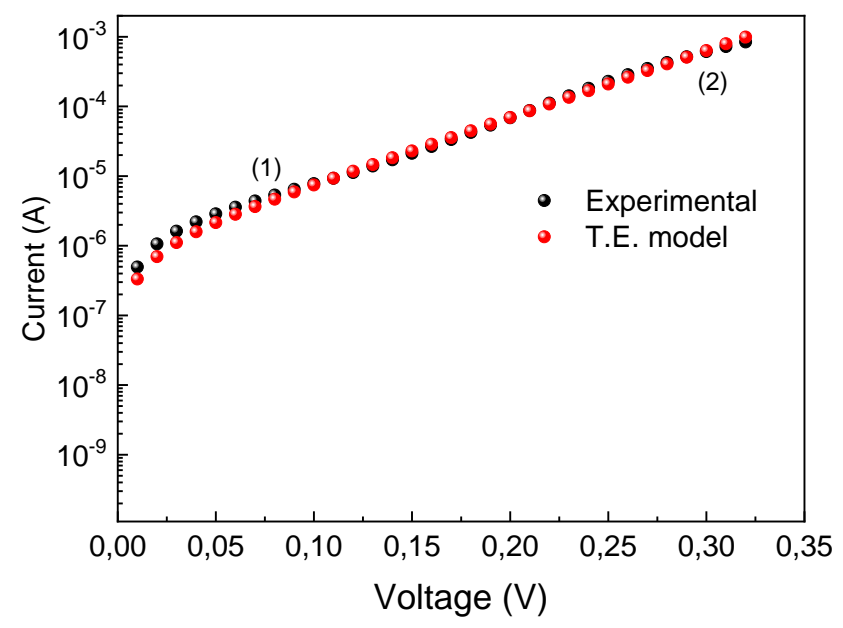

Fig. 2 - Current as a function of applied voltage of $\mathrm{Au} / \mathrm{InN} / n$ InP diode at room temperature (measured data and T.E. model)

The barrier height measured from the $I-V$ method is an effective value and can include barrier lowering effect due to the interfacial insulator layer or interface states. Furthermore, the determination of Schottky barrier height from $I$ - $V$ characteristics is only reliable if the forward current is a good straight line with a low value of the ideality factor. The analytical curve is compared with the experimental one. The results confirm that the conduction phenomenon can be described as thermionic emission. The series resistance $\left(R_{s}\right)$ is an important parameter for the electrical characteristics of Schottky diodes. Various methods were suggested to determine the efect of series resistance on electrical parameters of devices caused by the series resistance $R_{s}$. The value of the series resistance $R_{s}$ of $38 \Omega$ was estimated for higher polarization voltages from the slope of the $\ln [I / \exp (-q V / k T)]$ characteristic. These results are very comparable to the value of series resistance obtained by Akkal et al. on $\mathrm{Au} / \mathrm{InSb} / \mathrm{InP}$ (100) Schottky diode, where the series resistance was equal to $85 \Omega[11]$.

\subsection{Capacitance-Voltage Characteristics}

The capacitance of a Schottky diode varies with bias voltage as 


$$
\frac{1}{C^{2}}=\frac{2\left(V_{R}+V_{d}\right)}{q \varepsilon_{s} N_{D} A^{2}},
$$

where $V_{R}$ is the voltage in the reverse bias, $V_{d}$ is the diffusion potential, $\varepsilon_{s}=12.1 \varepsilon_{0}$ is the permittivity of the semiconductor, $\varepsilon_{0}=8.85 \times 10^{-14} \mathrm{~F} \cdot \mathrm{cm}^{-1}$ is the vacuum dielectric constant, and $N_{D}$ is the doping concentration. Fig. 3 shows the capacitance measurements of the sample at $1 \mathrm{MHz}$.

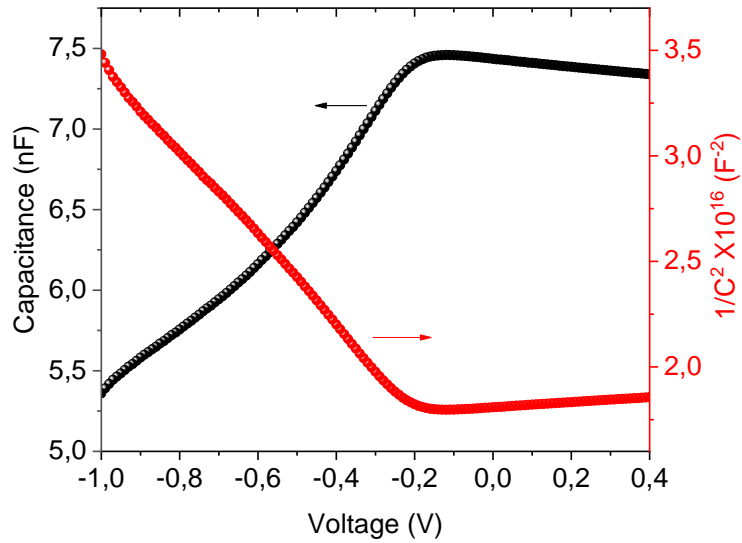

Fig. 3 - Capacitance-voltage characteristics of $\mathrm{Au} / \mathrm{InN} / \mathrm{InP}$ diode at $1 \mathrm{MHz}$

The capacitance reaches a maximum when electrons are accumulated at the interface because of the barrier high, and then decreases when it is under reverse bias. An increase in reverse bias shifts the Fermilevel downward for the InP side, which increases the depletion width and consequently increases the total positive charge of ionized donor atoms. As a result, the inverse of capacitance increases with increasing reverse bias. The barrier height from $C$ - $V$ measurement is defined by [12]:

$$
\Phi_{b n}=V_{d}+\frac{k T}{q}+V_{n},
$$

where $V_{n}$ is the Fermi energy determined from the conduction band.

The diffusion potential or built-in potential is measured by extrapolating $1 / C^{2}$ versus $V$ plot to the $x$ axis (Fig. 3). For Au/InN/InP Schottky diode, the calculated doping concentration $N_{D}$ and the diffusion potential are $1.16 \times 10^{17} \mathrm{~cm}^{-3}$ and $0.72 \mathrm{eV}$, respectively. The barrier height $\Phi_{b n}$ is evaluated to $0.83 \mathrm{eV}$; this value is lower than that obtained by the $I-V$ data. The discrepancy between $I-V$ and $C$ - $V$ measurements cannot be seen if the barriers are uniform and ideal, and the two measurements yield the same value. These different values obtained from the two techniques can be explained by a distribution of the Schottky barrier height due to inhomogeneities (combination of the interfacial InN layer composition, non-uniformity of the interfacial thickness, and distribution of interfacial charges) that occur at the interface $[12,13]$. The Schottky barrier calculated from $1 / C^{2}$ versus $V$ gives an idea of the mean value of nonhomogeneous Schottky barrier. Thus, any spatial variation on a barrier causes current preferentially through the minimum barrier which can explain this difference between the two extracted values.

The experimental parameters determined from $I-V$ and $1 \mathrm{MHz} C-V$ characteristics of Schottky diodes are given in Table 1.

The capacitance versus bias voltage characteristics were measured at room temperature and for different $\mathrm{AC}$ signal frequencies in the range of $1 \mathrm{kHz}$ to $1 \mathrm{MHz}$.

Table 1 - Experimental parameters obtained for Au/InN/InP Schottky diode

\begin{tabular}{|c|c|c|}
\hline Symbol & Parameter & Value \\
\hline$I_{s}$ & Saturation current & $12.3 \mu \mathrm{A}$ \\
\hline$n$ & Ideality factor & 1.57 \\
\hline$R_{s}$ & Series resistance & $38 \Omega$ \\
\hline$\Phi_{b n}$ & Barrier height from $I-V$ & $0.64 \mathrm{eV}$ \\
\hline$N_{D}$ & Doping concentration & $1.16 \times 10^{17} \mathrm{~cm}^{-3}$ \\
\hline$V_{D}$ & Diffusion potential & $0.72 \mathrm{~V}$ \\
\hline$\Phi_{b n}$ & Barrier height from $C-V$ & $0.83 \mathrm{eV}$ \\
\hline
\end{tabular}

In the ideal case, $C$ - $V$ measurements are frequency independent, however, the presence of interface states leads to a strongly frequency-dependent capacitance [14] as shown in Fig. 4. The value of the capacitance decreases with increasing frequency.

This occurs because at lower frequencies the interface states can follow the AC signal and yield an excess capacitance which depends on the frequency. At average frequencies, less interface states are bounded by the AC signal (there are different types of interface states with different lifetimes) which reduces the measured capacitance. At the high-frequency limit, the interface states cannot follow the AC signal. This makes the contribution of the interface state capacitance to the total capacitance negligibly small.

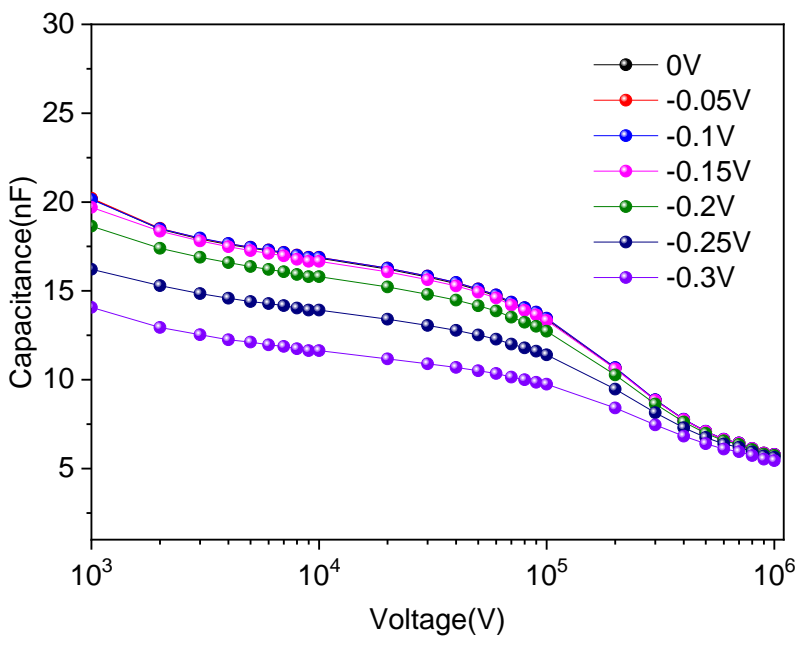

Fig. 4 - Capacitance-frequency for 0 to $-0.3 \mathrm{~V}$ bias showing the dispersion that occurs over the measured frequency range

\subsection{Determination of Interface States Density (Nss)}

In order to determine the density of the interface state distribution, the surface potential $\psi_{s}$ values have been extracted from measured $I-V$ characteristics. The electrical current of a Schottky diode as a function of the surface potential can be expressed as: 


$$
I=A A^{*} T^{2} \exp \left(\frac{-q V_{n}}{k T}\right) \exp \left(\frac{-q \psi_{s}}{k T}\right) .
$$

Fig. 5 represents the surface potential which we had extracted using Eq. (7) and the electrical current measurements by replacing experimental data in the following analytical expression:

$$
\psi_{s}=\frac{k T}{q} \ln \left(\frac{A A^{*} T^{2}}{I}\right)-V_{n} .
$$

The density of states in the conduction band edge is equal to $N_{C}=5.7 \times 10^{17} \mathrm{~cm}^{-3}$ for InP substrate [15]. $N_{D}$ doping concentration was extracted from the slope of $1 \mathrm{MHz}$ frequency $1 / C^{2}$ versus $V$ characteristics measurement at room temperature.

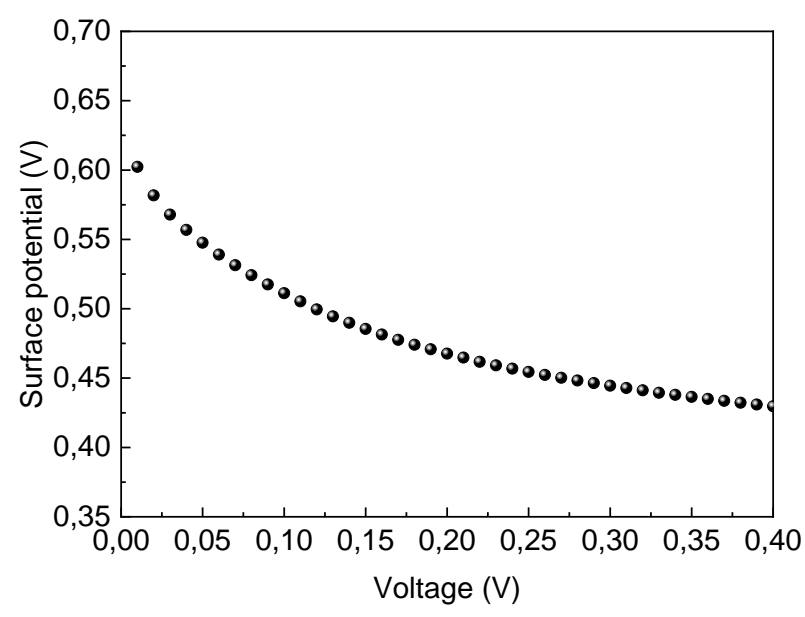

Fig. 5-Surface potential-voltage characteristics of $\mathrm{Au} / \mathrm{InN} / \mathrm{InP}$ diode

The interface states have different lifetimes. At low frequencies, all interface states follow the AC signal, and the low-frequency capacitance is given by [16]:

$$
C_{L F}=\frac{\sqrt{q \varepsilon_{s} N_{D} / 2 \psi_{s}}+q N_{s s}}{1+q J R_{s} / k T^{+\delta / \varepsilon_{i}\left(\sqrt{q \varepsilon_{s} N_{D} / 2 \psi_{s}}+q N_{s s}\right)}},
$$

where $N_{S S}$ is the interface state density, $\delta$ is the thickness of the interfacial layer, $\varepsilon_{i}$ and $\varepsilon_{s}$ represent the permittivity of the interfacial layer and that of the semiconductor, respectively.

At high frequencies, theoretically none of the interface states follows the AC signal, therefore the interface states have no effect on the capacitance, and the capacitance can be expressed [16]:

$$
C_{H F}=\frac{\sqrt{q \varepsilon_{s} N_{D} / 2 \psi_{s}}}{1+q J R_{s} / k T^{+} \delta / \varepsilon_{i} \sqrt{q \varepsilon_{s} N_{D} / 2 \psi_{s}}} .
$$

The interface state density $N_{S S}$ can be determined using Eqs. (9) and (10) such as:

$$
N_{s s} \approx \sqrt{q \varepsilon_{s} N_{D} / 2 \psi_{s}} \frac{C_{L F}-C_{H F}}{q C_{H F}} .
$$

The interface state density $N_{S S}$ was calculated using the experimental $C-V$ at a low frequency $(1 \mathrm{kHz})$ and $C-V$ at a high frequency $(1 \mathrm{MHz})$ by using Eq. (11). Furthermore, in $n$-type semiconductors, the energy of interface states with respect to the top of the conduction band $\left(E_{C}-E_{S S}\right)$ at the surface of the semiconductor is given by [17]:

$$
E_{c}-E_{s s}=q\left(\Phi_{b n}-V\right) .
$$

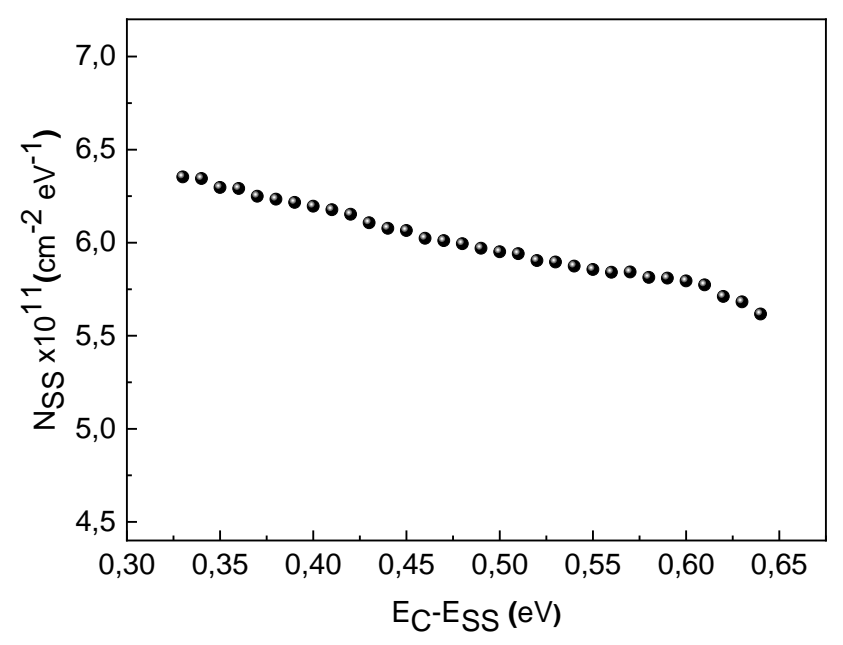

Fig. 6-Interface state density energy distribution of $\mathrm{Au} / \mathrm{InN} / \mathrm{InP}$ diode by L-H frequency $C-V$

Fig. 6 represents the interface state density as a function of energy. The value of the interface state density $N_{S S}$ decreases with energy increasing from the edge of the conduction band. As can be seen, the near mid gap interfacial state density $N_{S S}$ is estimated equal to $5.6 \times 10^{11} \mathrm{~cm}^{-2} \mathrm{eV}^{-1}$. Due to the elimination of surface contaminants such as oxygen and carbon impurities by the ionic bombardment cleaning of the InP substrate surface, a lower interface state density was found. Additionally, after the nitridation process, the interfacial crystallographic defects were improved by the formation of the InN layer. This result is reasonable considering the high concentration of defects in nitride materials [17] and in good agreement with those obtained by A. Rabehi et al. [18] and A.H. Kacha et al. [4] on GaAs substrates. The results yield that the interface states play a very important role in the current flow mechanism in electronic devices, and they must be kept as low as possible in order to reduce the surface recombination and tunneling.

\section{CONCLUSIONS}

We reported in this paper the electrical characterization of the $\mathrm{Au} / \mathrm{InN} / n$-InP structure. We demonstrated that the $I-V$ and $C$ - $V$ curves of this diode are influenced by the presence of the InN layer. A low saturation current and series resistance were obtained. The effective barrier heights were $0.65 \mathrm{eV}$ and $0.83 \mathrm{eV}$ from $I-V$ and $C-V$ measurements, respectively. The interface state density $N s s$ was significantly low $\left(5.6 \times 10^{11} \mathrm{~cm}^{-2} \mathrm{eV}^{-1}\right.$ 
at mid gap) compared to that of conventional $\mathrm{Au} / n$-InP Schottky diodes. We concluded that the prepared $\mathrm{Au} / \mathrm{InN} / n$-InP Schottky diode by passivating the $\mathrm{InP}$ surface with the formation of the interfacial InN layer improves the diode characteristics by reducing the interface states density.

\title{
REFERENCES
}

1. G. Koblmuller, C.S. Gallinat, S. Bernardis, J.S. Speck, G.D. Chern, E.D. Readinger, H. Shen, M. Wraback, Appl. Phys. Lett. 89 No 7, 071902 (2006).

2. K. Wang, R.R. Reeber, Appl. Phys. Lett. 79 No 11, 1602 (2001).

3. M. Petit, Ch. Robert-Goumet, L. Bideux, B. Gruzza, Z. Benamara, N. Bachir Bouiadjra, V. Matolin, Appl. Surf. Sci. 234, 451 (2004).

4. A.H. Kacha, B. Akkal, Z. Benamara, M. Amrani, A. Rabhi, G. Monier, R. Goumet, L. Bideux, B. Gruzza, Superlattice. Microstruct. 83, 827 (2015).

5. M. Petit, Y. Ould-Metidji, C. Robert, L. Bideux, B. Gruzza, V. Matolin, Appl. Surf. Sci. 212/213, 601 (2003).

6. A. Talbi, Z. Benamara, B. Akkal, B. Gruzza, L. Bideux, C. Robert, C. Varenne, N. Chami, Mater. Sci. Eng. A 437, 254 (2006).

7. S.M. Sze, Physics of Semiconductor Devices. 3rd Ed. (New York: John Wiley and Sons: 2006).

8. H. Mathieu, H. Fanet, Physique des Semiconducteurs et des Composants Électroniques (Dunod, Paris, 6e ed., 2009).

9. H. Çetin, E. Ayyildiz, Semicond. Sci. Technol. 20, 625 (2005).

10. H. Çetin, E. Ayyildiz, J. Vac. Sci. Technol. B 23, 2436 (2005).

11. B. Akkal, Z. Benamara, N. Bachir Bouiadjra, S. Tizi, B. Gruzza, Appl. Surf. Sci. 253, 1065 (2006).

12. M.K. Hudait, S.B. Krupanidhi, Mater. Sci. Eng. B 87 No 2, 141 (2001).

13. E.H. Nicollian, A. Goetzberger, Appl. Phys. Lett. 7, 216 (1965).

14. E.H. Rhoderick, Metal-Semiconductor Contacts (Oxford University Press) 121, 136 (1978).

15. M. Levinstein, S. Rumyantsev, M. Shur, Handbook Series on Semiconductor Parameters (World Scientific: London: 1996).

16. S. Chattopadhyay, L.K. Bera, S.K. Ray, P.K. Bose, C.K. Maiti, Thin Solid Films 335 No 1-2, 142 (1998).

17. Christopher F. McConville, William J. Schaff, Indium Nitride and Related Alloys (CRC Press: 2011).

18. A. Rabehi, M. Amrani, Z. Benamara, B. Akkal, A.H. Kacha, Optik 127 No 16, 6412 (2016).

\section{Електричні характеристики та густина інтерфейсних станів в діоді Шотткі Au/n-InN/InP}

\author{
A.H. Khediri ${ }^{1,2}$, A. Talbi ${ }^{1}$, M.A. Benamara ${ }^{1}$, Z. Benamara ${ }^{1}$ \\ ${ }^{1}$ Laboratoire de Microélectronique Appliquée, Université Djillali Liabès de Sidi Bel Abbès, 22000, Algeria \\ 2 Plateforme Technologique de Micro-fabrication, Centre de Développement des Technologies Avancées, Cité 20 août \\ 1956, Baba Hassen, 16303 Algiers, Algeria
}

\begin{abstract}
$\mathrm{y}$ роботі представлено електричне дослідження тонких плівок $\mathrm{InN}$, розроблених шляхом нітрування підкладки InP (100). Зразки були отримані з використанням джерела тліючого розряду (GDS) в надвисокому вакуумі. Золотий (Au) контакт Шотткі був нанесений на верхню частину поверхні. Електричні характеристики структури $\mathrm{Au} / \mathrm{InN} / n-\mathrm{InP}$ були досліджені з використанням BAX та кривих емність-напруга. 3 BAX при кімнатній температурі показано, що основним механізмом провідності е струм термоелектронної емісії. Значення коефіціента ідеальності діода 1,57 знаходять за допомогою аналітичних методів. Крім того, висота бар'єру пристрою оцінюеться в 0,64 еВ. Це значення значно більше, ніж раніше повідомлене в літературі. Низький струм насичення та послідовний опір $\left(R_{s}\right)$, рівні відповідно 12,3 мкА та 38 Ом, вказують на наявність шару $\mathrm{InN}$. 3 кривих емність-напруга при напрузі зворотного зміщення отримують вбудований потенціал та концентрацію іонізованого донора $0,83 \mathrm{~B}$ та $1,16 \times 10^{17} \mathrm{~cm}^{-3}$ відповідно. Частотно-залежну емність пояснюють наявністю інтерфейсних станів. На основі методу високих і низьких частот визначено середню густину інтерфейсних станів (Nss) рівну $5,6 \times 10^{11} \mathrm{eB}^{-1} \mathrm{~cm}^{-2}$. Ці висновки свідчать про гарну пасивацію поверхні InP із використанням тонкої плівки $\mathrm{InN}$.
\end{abstract}

Ключові слова: Висота бар'еру, Вимірювання ВАХ, Фосфід індію, Нітрид індію, Густина інтерфейсних станів, Діоди Шотткі. 